\title{
Strategic Communication in Crisis Governance: Analysis of the Singapore Management of the SARS Crisis
}

Yan Jin, Augustine Pang and Glen T. Cameron

\begin{abstract}
The contingency theory of conflict management and current crisis management literature are integrated in this paper to examine how crisis has been communicated and managed by the Singapore government and what kinds of strategies arose during the various stages of the SARS crisis life-cycle. Findings show that the Singapore government played a predominant role in managing how its multiple publics perceived the crisis by extensive communication through the news media. The media, in turn, playing a supporting nation-building role, assisted the government's management and communication of the crisis. To effectively manage the perception and emotion of the various public, the government had recourse to more accommodative stances. Accommodation embedded in advocacy was the operational approach adopted by the government in order to move its multiple publics in the same strategic direction along an continuum of accommodation.
\end{abstract}

Keywords: Crisis Communication; Singapore; Media; Contingency Theory; SARS; Publics

\section{Introduction}

For several months in 2003, the world was besieged by a strain of virus that masqueraded as pneumonia but inflicted a far more lethal effect. By all accounts, the mystery of how the SARS (Severe Respiratory Acute Syndrome) virus originated has remained largely unsolved (New York Times, 24 May 2003: 1). What began as routine fever and cough in a Chinese physician, later identified as a super-carrier, rapidly spread to those who came into cursory contact with him, spiralling into a worldwide crisis and infecting people across Asia and as far as Canada (New York Times, 27 April 2003: 1).

SARS arrived in Singapore, a cosmopolitan city-state nestled at the tip of Malaysia, when three women fell ill after a visit to Hong Kong in Febru- 
ary 2003. Infected by people who had been infected by the super-carrier, the women, in turn, infected others until it became an epidemic of crisis proportions. By early March, a SARS 'ministerial combat unit', comprising five junior government ministers (The Straits Times [hereafter ST]. 4 May 2003: 1\}, had been set up by the government to direct and co-ordinate efforts to fight SARS. On 18 March 2003, Singapore entered the World Health Organization's (WHO) list of SARS-hit countries. With the escalation of the crisis, a 'ministerial task force', comprising a high-powered committee of five senior government ministers and four junior ministers, representing a cross-spectrum of agencies ranging from health to education, transport and information, was promptly formed (ST, 7 April 2003: 1). The following months marked the frenetic pace at which the Singapore government worked to contain and communicate the SARS crisis to the different segments of the public, eventually leading the WHO to declare Singapore SARS-free on May 31. The WHO's verdict on the government's handling of the crisis was 'Exemplary' (ST, 1 June 2003: 1).

Most studies on the SARS crisis have focused on the local level, on the relationship between the organization and its public (Dougherty 1992; Seegar and Ulmer 2002; Wigley 2003). These studies analysed the strategies used by organizations communicate with their respective publics, such as employees, stakeholders, the media, and the community, when the organization appeared to be culpable (Fink 1986; Fearn-Banks 2002; Henry 2000; Pauchant and Mitroff 1992). Some studies have focused on communication strategies (Booth 1993; Barton 1994; Ray 1999; Lukaszweski 1997; Henry 2000; Cohn 2002; Davis and Gilman 2002) and communication planning (Marra 1998; Ferguson 1999). Other studies have centred on relationship/issues management and media relations (Pauchant and Mitroff 1992; Barton 1993, Harrison 1999; Massey 2001; Ulmer 2001; Cowden and Sellnow 2002; Seegar and Ulmer 2002), particularly at times of organizational culpability and crisis responsibility.

However, few studies have sought to examine how the crisis was communicated by the government at a strategic national level, especially when culpability could not immediately be determined. Yet, as Rosenthal and Kouzmin (1997) have argued, it is critical to understand the roles governments play in times of crises, particularly when the threat, as in a crisis like SARS, exists in the socio-political system. At such times there is a necessity for prompt decision-making by the government, and a need to engage the public fully in whatever remedial approach it seeks to promote. The criticality of communication roles, we argue, is heightened in times of crisis. 
This study seeks to examine how crisis is communicated and managed at the macro level, between the government and its diverse publics, and to understand the kinds of strategic communication stances and strategies used in a crisis situation. Besides contributing a new theoretical perspective to the crisis literature by integrating the contingency theory of conflict management with current crisis literature, this study sheds light on the strategic communication approach used by a government during crisis governance. The critical role the media played in this crisis communication campaign will also be explored. It is hoped that this study will generate practical insights for governmental strategic communication practitioners on the most appropriate strategic communication approaches and techniques to be adopted in similar scenarios.

\section{Literature Review and Research Questions}

\section{Development of Crisis Theories in Public Relations Research}

Much of the literature on effective public relations at times of crisis has been built on Grunig and Grunig's (1992) and Grunig and Hunt's (1984) public relations' excellence theory, which Fearn-Banks (2002:15) argued, forms the 'bedrock of most crisis communications theories'. The mainstay of the excellence theory, the two-way symmetrical model which postulates that during a crisis, both the organization and its publics should engage in active dialogue so as to resolve the crisis in a professional, ethical and effective way, has been positioned as normative theory (Fearn-Banks 2002).

However, instead of clustering and pigeon-holing public relations practices and techniques into rigid and inflexible models, an alternative perspective has argued that strategic communication could more accurately be portrayed through a continuum model. The continuum, argued Cancel and colleagues (1999: 172), explains 'an organization's possible wide range of stances taken toward an individual public, differing from the more proscriptive and mutually exclusive categorization'. In the contingency theory of conflict management, Cameron and his colleagues took the idea of continuum further by examining how organizations practise a variety of stances, how those stances change, sometimes almost instantaneously, and what influences the stance change (Cancel et al. 1997).

The organizational response to the crisis at hand, according to the contingency theory, can situate at any point along the continuum, which 
has, at one end, advocacy, and at the other end, accommodation. The theory offers a matrix of about 90 factors, arranged thematically, upon which the organization can draw to determine their stance. Between advocacy and accommodation is a wide range of operational stances that influence strategies and these 'entail different degrees of advocacy and accommodation' (Cancel et al. 1997: 37). Any of these factors can affect the location of an organization on that continuum 'at a given time regarding a given public' (Cancel et al. 1999: 172; Yarbrough et al. 1998: 40). The contingency theory sought to understand the dynamics, within and without the organization, that affect a given stance. By understanding these dynamics, it elaborates and specifies the conditions, factors and stances along a continuum, aiming to 'offer a structure for better understanding of the dynamics of accommodation as well as the efficacy and ethical implications of accommodation in public relations practice' (Yarbrough et al. 1998: 41).

This study aims to identify the strategies and contingent factors that affect the organization's operational stance towards its multiple publics. The organization, in this case, is the Singapore government, which includes any government-related agency, such as the Ministry of Health, National Environment Agency, or Agri-Food and Veterinary Authority, involved in fighting SARS.

By the same token, while the contingency theory recognizes that there can be numerous publics to be addressed at a given time, any attempt to deal with the public relations stance that encompasses all the publics is 'difficult at best' (Cancel et al. 1997: 37). Ray (1999) and Gonzalez-Herrero and Pratt (1996) supported this observation. What is known, however, is that the publics are dynamic and can take different forms, and hence the stances taken towards them must be equally, if not more, dynamic.

New insights of studies of the contingency theory found that the publics are not 'monolithic', and the issues and the publics can be interwoven to form a cohesive whole that is dynamic and often 'long-lived' in public memory (Yarbrough et al. 1998: 54). Thus, another purpose of this study is to identify, deductively, who the publics are in this crisis, and to understand what contingent factors appear to move the stances of the organization, and what contingent factors appear to move the publics on the continuum of accommodation.

Our questions are, therefore:

$Q$ 1.1: How did the stances of the Singapore government toward the publics differ over time, as evident in the news coverage? 
$Q$ 1.2: How did the stances of the different publics toward the Singapore government differ over time, as evident in the news coverage?

$Q$ 1.3: What contingent factors appeared to affect the stances of the Singapore government, as evident in the news coverage?

$Q$ 1.4: What contingent factors appeared to move the Singapore government as well as the publics on the continuum of accommodation, as evident in the news coverage?

\section{Crisis Communication Strategies along the Continuum}

Scholars also found that some contingent variables feature more prominently than others. Studies on the contingency theory have shown that certain key variables predisposed an organization to accommodation while others prohibited any form of accommodation. Then, there are other intermediate variables that have the power to steer the organization towards either more accommodation or advocacy, depending on the prevailing circumstances.

Cameron and his colleagues (2001) argued that there are times when accommodation is not possible at all, owing to moral, legal and regulatory reasons. He labelled them proscriptive variables. Six have been identified:

1. When there is moral conviction that an accommodative or dialogic stance towards a public may be inherently unethical;

2. When there is a need to maintain moral neutrality in the face of contending publics;

3. When legal constraints curtail accommodation;

4. When there are regulatory restraints;

5. When senior management prohibits an accommodative stance; and

6. When the issue becomes a jurisdictional concern within the organization and resolution of the issue takes on a constrained and complex process of negotiation.

Of the six variables, four - moral conviction, contending publics, legal constraints and jurisdictional issues - preclude accommodation 'on some occasions' (Cameron et al. 2001: 255).

To study the full range of advocacy or accommodation undertaken by the organization towards its publics and vice versa, we have integrated Coombs's (1998) crisis communication strategies into the contingency framework. Coombs's typology consists of seven strategies: attack, denial, excuse, corrective action, justification, ingratiation and full apology. To reflect the true spirit of the contingency theory, we have 
modified this framework by re-ordering corrective action and justification, and by adding another strategy, co-operation, to the continuum (see diagram below).

\begin{tabular}{|c|c|c|}
\hline 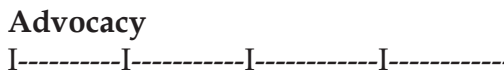 & 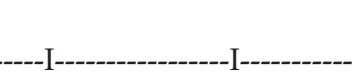 & $\begin{array}{l}\text { Accommodation } \\
-\end{array}$ \\
\hline Attack Denial Excuse Justification & $\begin{array}{l}\text { Corrective Ingratiation } \\
\text { Action }\end{array}$ & $\begin{array}{r}\text { Co-operation Full } \\
\text { Apology }\end{array}$ \\
\hline
\end{tabular}

Given the range of strategies that can be used, we wanted to find out: $Q$ 2.1: What strategies utilized by the Singapore government were evident in the news coverage?

$Q$ 2.2: What contingent factors appeared to affect the strategies of the Singapore government in the crisis, as evident in the news coverage?

\section{Publics in a Crisis}

Publics are 'specific audiences' targeted by the organization. Davis and Gilman (2002) argued that a key role the organization should embark on in a crisis is to identify the publics and develop appropriate messages to reach out to them. Ray (1999) posited that because the publics have different perceptions of what caused the crisis, the organization's communication with them could ameliorate any unfounded anxieties. Plowman et al. (1995) suggested that the role of strategic communication in a crisis centres on the management of conflict between the organization and its important stakeholders. Coombs (1999) argued that an organization thrives or survives by focusing and managing the stakeholders.

In a crisis, the publics have been defined differently, according to their importance to resolving situation, their functional roles and their long-term influences. Lukaszweski (1997) argued that there are four key publics that the organization must communicate with, and that communication must begin as soon as possible. They are:

- those most directly affected, the victims;

- the organization's employees, who may bear the brunt of the publics' wrath;

- those indirectly affected like families and relatives;

- the news media and other channels of external communication.

Harrison (1999) argued that local community and pressure groups, and the government could form the next significant layer of the publics.

Dougherty (1992) preferred to examine the publics in terms of their functional roles and proposed four categories. Enabling publics, which 
include shareholders, board of directors and regulatory agencies, have the power and authority to control the organization's resources. Functional publics mainly consist of the organization's consumers. Normative publics are formed because of shared values, like political or interest groups. Diffused publics are people who are not members of a formal organization, yet, nonetheless, are powerful groups; they include the media and interested citizens. Ulmer (2001) categorized the publics in terms of their long-term influences. He perceived the primary public as the community in which the organization works, and the employees. The customer and the media he classified as a secondary public.

\section{Publics' Perception and Emotion of the Publics in a Crisis}

Fink (1986: 20-25) developed a four-stage model of a crisis life-cycle:

1. Prodromal crisis stage, or the warning stage;

2. Acute crisis stage, or when the crisis happens;

3. Chronic crisis stage, or the clean-up stage; and

4. Crisis resolution stage, or when dust has settled and evaluations are made to assess how the crisis has been handled and what can be done to deal with the next one.

Pauchant and Mitroff (1992: 135-40) argued for a five-stage model that includes:

1. Detection of the crisis, or looking out for warning signs;

2. Prevention/preparation of the crisis, or what can be done to prepare for its occurrence;

3. Containment, or efforts to limit the duration of the crisis and localize it;

4. Recovery, or restoring order and normalcy to the organization; and

5. Learning, or the process of evaluating the crisis and examining what lessons can be learnt from it.

In his three-stage model, Coombs posited a 'unified system' that could 'accommodate all the various models plus additional insights' (1999: 14). The three-stage model comprises the precrisis, crisis and postcrisis stages. The pre-crisis stage entails actions that organizations perform before a crisis hits. It involves three sub-stages: signal detection, prevention and crisis preparation. Among the measures suggested here are issues management, risk aversion and relationship building. The crisis stage involves the actions the organization can perform from the onset of the crisis to the time it is resolved. Coombs further divided this into three sub-stages: crisis recognition, crisis containment and business resumption. Critical to this phase is communication with the publics. Coombs 
argued that the last stage, the post-crisis stage, is equally important even though the crisis is officially over. Organizations must consider how to be better prepared for the next crisis and make sure that stakeholders are left with a positive impression of the organization's crisis management efforts.

In this study we do not intend to precisely plot the life-cycle of the crisis through the coding of news stories. We propose instead to utilize Gonzalez-Herrero and Pratt's (1996) paradigmatic development of a crisis model as a more appropriate reflection of the life-cycle of the SARS crisis; we will do this by generally looking at the crisis from birth, growth, maturity to decline. As the strategies the Singapore government employed varied over time, we propose that its publics' cognitive and affective responses to the organization's performance should also reflect the life-cycle of the crisis.

Perceptions of the severity of the crisis can actualize in two ways: (1) perceptions of culpability and (2) perceptions of the locus of control of the crisis. Coombs (1998) argued that if the organization is perceived by its publics as culpable, it is more likely to utilize more accommodative strategies to control the damage. Consequently, if the publics perceive that the locus of control of the crisis lies with the organization, the perception of its crisis responsibility increases. Conversely, if the publics perceive the locus of control to be external to the organization, the perception of crisis responsibility decreases.

In this study, besides finding out where the Singapore government and its publics perceived the locus of crisis control to be, we also investigate how the perception of one party influenced that of the other. Thus, we seek to examine:

$Q$ 3.1: What was the perception of the Singapore government and its multiple publics in the crisis situation, regarding crisis attribution and crisis damage severity, as evident in the news coverage?

$Q$ 3.2: How did the perception of the Singapore government's performance, as evidenced in the news coverage, vary among the multiple publics involved?

$Q$ 3.3: What contingent factors appeared to affect the publics' perception of the Singapore government's performance in the crisis, as evidenced in the news coverage?

Jin and Cameron (2003) called for greater attention to the construct of emotion in public relations theory by providing an adapted appraisal model of emotion in public relations and a crucial dimension to the conceptualization of the contingency theory. They further proposed 
that any given stance can be assessed as a relational encounter with emotional forces that conform to a model expressed in three dimensions: (1) emotional tone as the valence of the emotion ranging from negative to positive; (2) emotional temperature as the intensity level of the emotion; and (3) emotional weight regarding the importance of the emotional stimulus in strategic consequences (Jin and Cameron 2003: 16-17). Since the perceived severity works as emotional weight here, we are particularly interested in examining the emotional tone and temperature as two key dimensions of the publics' emotion towards the organization in the crisis situation. Therefore, we seek to examine:

$Q$ 4.1: What was the nature and strength of the multiple publics' emotion toward the Singapore government in the crisis situation, as evident in the news coverage?

$Q$ 4.2: What strategies appeared to affect the publics' emotion toward the Singapore government in the crisis, as evident in the news coverage?

\section{Method}

This study employs the content analysis method to understand how the Singapore government managed the SARS crisis by strategically communicating with its multiple audiences through the media. Due to the rapidity, abruptness and volatility of the situation, and the exigency and imperative to communicate the crisis as efficiently and effectively as possible, the authors argue that analysis of the government's stance and strategies, as well as the publics' responses, through a study of news coverage, will provide an accurate representation of what happened.

With every quick turn of events during the crisis, the government needed to communicate with its publics speedily. Arguably, the only way that it could do this was through a public platform that was accessible to most, if not all, of its publics, i.e., through the media. Martinelli and Briggs (1998) argue that in a crisis, the media become an important tool to examine an organization's stances and strategies, and the effectiveness with which it gets its messages across to its publics, rather than other means, like government-issued press releases.

To capture the stance and strategies of the Singapore government through the media, only newspaper reports were analysed. Newspaper articles, often referred to as public records of history in the making (Warrington 1997), are argued to provide a more detailed, comprehensive and chronological account of the management of the crisis than messages 
disseminated through television coverage, which are arguably more episodic and fleeting. In Singapore, the dominant newspaper is The Straits Times (established 1845). It is the highest circulating and most popular newspaper, with a readership of 1.351 million, representing 42 percent of newspaper readers (ST, 6 October 2004: H6). It is a prestige newspaper of international standing (Turnbull 1995). Kuo and Ang maintain that The Straits Times is 'pro-government and pro-Establishment' (2000: 415), and that arguably, aiding the government in a national crisis like SARS, can be considered as part of its nation-building responsibilities. The elites and general readers monitor the newspaper as it often reflects government sentiments and the social reality that the government constructs for Singapore (Turnbull 1995). Thus, by focusing our analysis on the news reports in a prestige newspaper like The Straits Times, we endorse the view of Krippendorf (2004) and Riffe et al. (1998), that this approach will project a fair representation of the government's efforts, intentions, stances and strategies.

Indeed, previous studies analysing an organization's strategic communication stances through newspaper coverage have proved equally insightful (see Reber et al. 2003 Shin et al. 2003a, 2003b) Though we recognize the inherent methodological limitations of this approach, we would argue that these do not invalidate our purpose of determining which factors could have caused the Singapore government to move along the continuum towards its publics.

\section{Sample}

The population of stories from 18 March 2003, when Singapore was declared by WHO as SARS-hit, to 7 June 2003, when Singapore was declared SARS-free, were sampled. Stories were uploaded from LexusNexus by typing in the key words, 'SARS' and 'Singapore'. This yielded 2,018 stories. From the stories, the authors screened all of them based on the following criteria: (i) no editorials, opinions, commentaries or letters to the editors; (ii) at least two parties should be involved in the SARS story, with one of the parties being the Singapore government; and (iii) if there was more than one public involved in the same story, the dominant public would be identified as the prominent public for the story under analysis. To further delineate the selection of stories, up to four news stories that fitted the criteria stated above were identified from each issue. If there were fewer than four news stories published in an issue, all the available stories were chosen for sampling.

The 2,018 stories were filtered down to 258 stories which captured how 
the Singapore government related to its publics. Five types of publics were identified: $\mathrm{WHO}(\mathrm{N}=11)$, service professionals (including medical professionals such as doctors and nurses, taxi-drivers, and other service professionals, $\mathrm{N}=52)$, neighbouring countries $(\mathrm{N}=34)$, quarantined public (patients and/or suspects) $(\mathrm{N}=68)$ and the general public $(\mathrm{N}=93)$.

\section{Coders and Training}

Two coders, both graduate students familiar with the content analysis method, conducted the analysis. With the help of a codebook, the coders worked independently. Scott's Pi for intercoder reliability was $.84(\mathrm{p}<$ .05). Chi-square, T-test, and ANOVA were used to analyse the data.

\section{Coding Instrument}

The unit of analysis is defined as any news story. This includes stories by the staff of the newspaper and wire stories. The content analysis instrument is designed to evaluate the stances and strategies of an organization in crisis management, its multiple publics' stances and perceptual as well as emotional responses to the organization's performance, and the contingent factors associated with the stances and strategies of the above parties. The operational definitions of stance and contingent factors are framed by the contingency theory and the crisis management literature. The 258 news stories were coded for 19 variables. These include: case source; news story number; publics involved in the crisis; the overall impression on the stance of the organization toward the according public; the overall impression on the stance of a specific public toward the organization; crisis strategy employed by the organization; the organization and the multiple publics' perception of the crisis situation; the public's perception of the organization's performance; and the public's emotion toward the organization in the crisis.

Adapting and merging Coombs's (1998) crisis communication strategies into Cameron's continuum model of advocacy and accommodation, we propose to measure the government's strategies in terms of:

1. Attack: Actively advocating that the public follow a certain course of action;

2. Denial: Stating that the culpability does not rest with the party in question, or denying that the crisis is of any consequence;

3. Excuse: Minimizing its responsibility for the crisis, and/or shifting responsibility of the crisis to an external factor;

4. Justification: Explaining why it has to take a certain course of action; 
5. Corrective action: Actively taking a course of action that is meant to address the problems in sight;

6. Ingratiation: Actively taking a course of action aimed to placate its publics.

7. Co-operation: Making overtures to reach out to the other party with the goal of resolving the problem;

8. Full apology: Taking full responsibility for the crisis and asking for forgiveness.

As for the contingency factors, we realized that we would not be able to analyse which internal factors in the matrix would cause the movement along the continuum purely through content analysis of news coverage. We have therefore decided to focus our analysis on the external variables, which we can possibly detect from content analysis. The key factors and their operationalizations are:

1. Threats: Stories that address the SARS virus, how dangerous it is; the SARS crisis and how it needs to be contained;

2. Industry environment: Stories that describe the impact SARS had on the economy and market;

3. General political/social environment/cultural environment: Stories that deal with political support for the people, political support for businesses; stories that show the organization wanting to lend the extra help to the people; stories that portray the organization trying to improve the livelihood of the people;

4. External public: Stories that address the unique characteristics of the public. For instance, if the public is the medical professionals, stories about the difficulties medical professionals face vis-à-vis the organization in trying to contain SARS;

5. Issue under question: Stories that address the image and reputation of the organization and its people;

6. Others: Stories that do not address any of the above.

Each story is coded as one entry and as a single primary issue.

\section{Results}

The data show that the government's stance toward different publics changed over time, according to external contingent factors associated with the changes. The dominant crisis management strategy employed by the government across the crisis life-cycle also varied according to different publics. The different publics demonstrated different stances across time. Contingent factors were found to be associated with those differences. 
Q 1.1 examined how the stances of the organization and its multiple publics moved along a continuum during the crisis. It was found that, for each pair of the government and a specific public, the two parties involved moved along a continuum from advocacy to accommodation in the crisis management process. The government accommodated to some publics consistently while advocating with other publics. For example, on the one hand, the government $(\mathrm{M}=6.64)$ and WHO $(\mathrm{M}=5.45)$, government $(\mathrm{M}=5.04)$ and service professionals $(\mathrm{M}=5.75)$, and government $(M=4.03)$ and neighbouring countries $(M=4.02)$ generally accommodated in the crisis process, with no stance difference showing in paired t-tests. For instance, it emerged during the crisis that the service professionals who were caring for the victims were also infected with the virus. Of the 31 victims who had died by the end of May, five were service professionals. The government, in recognition of their heroic efforts, was relentless in providing financial and moral support for these professionals, beginning with free medical care and culminating in the establishment of a Courage Fund, targeted to raise US\$14.7 million (S\$25 million) to honour them. The chairman of the Board of Trustees wrote, 'This is your strongest message to our healthcare workers that they are not alone in the fight against SARS' (ST, 27 May 2003: 1).

On the other hand, the stances between government $(\mathrm{M}=2.99)$ and quarantined public $(\mathrm{M}=6.38)$, and government $(\mathrm{M}=3.35)$ and general public $(M=6.62)$ were marked by advocacy over time. Results also found that the government advocated strongly against the quarantined public $(t=-8.045, \mathrm{p}<0.01)$ and the general public $(\mathrm{t}=-8.290, \mathrm{p}<0.01)$. Consistently, they used the full weight of the law to deal with people who broke their quarantines or who indiscriminately jeopardized the health of others by spitting. Invoking the Infectious Diseases Act, quarantine breakers were jailed (ST, 10 May 2003:1) while those caught spitting were fined (ST, 21 May 2003: 1).

In addition, significant mean differences were found by comparing the stances of the five publics $(\mathrm{F}=4.13, \mathrm{p}<.01)$. It was revealed that service professionals and the general public were most accommodative as reported in the news coverage, while neighbouring countries were mostly advocatory across time, as described in the news coverage.

Q 1.2 and Q 1.3 examined the contingent factors that affected each paired parties' stances in the crisis on the continuum. Threat seemed to be the predominant contingent factor in several instances:

1. In the government's stance towards the service professionals $(44.2 \%$, $\left.\chi^{2}=85.550, \mathrm{p}<.001\right)$ and vice-versa $\left(36.5 \%, \chi^{2}=74.647, \mathrm{p}<.001\right)$; 
2. In the government's stance towards neighbouring countries $(44.1 \%$, $\left.\chi^{2}=68.330, \mathrm{p}<.01\right)$ and vice-versa $\left(44.1 \%, \chi^{2}=45.740, \mathrm{p}<.01\right)$;

3. In the government's stance towards quarantined public $(77.9 \%$, $\left.\chi^{2}=25.984, \mathrm{p}<.05\right)$ and vice-versa $\left(47.1 \%, \chi^{2}=81.163, \mathrm{p}<.001\right)$;

4. In the government's stance towards the general public $(64.5 \%$, $\left.\chi^{2}=55.554, \mathrm{p}<.001\right)$ and vice-versa $\left(32.3 \%, \chi^{2}=170.633, \mathrm{p}<.001\right)$.

What became evident was that from the beginning, the government had identified and isolated the SARS virus as the common enemy that everyone should battle against. Consequently, it was able to galvanize its publics to join its battle to overcome the enemy.

Q 2.1 examined the communication strategies the government employed towards its multiple publics. It found that:

- With the WHO it used co-operation (54.5\%) and corrective action $(18.2 \%)$;

- With service professionals it used co-operation (30.8\%), ingratiation $(26.9 \%)$ and attack $(21.2 \%)$;

- With neighbouring countries it used co-operation (33.3\%), attack $(41.0 \%)$ and justification (11.8\%);

- With the quarantined public it used attack (47.1\%) and co-operation (19.1\%);

- With the general public it used attack (31.2\%) and co-operation $(24.7 \%)$.

For instance, throughout the crisis campaign, while the government continually exhorted the general public to practise hygiene to prevent the spread of SARS, and was generally successful in doing so, it also sprinkled words of encouragement to affirm their efforts. The government's use of diametrically opposing stance and strategies concomitantly may, perhaps, be exemplified by the words of the Singapore prime minister: 'I complain about their [the general public's] complaining all the time. But that's part of our character. When it comes down to the basics, I have tremendous confidence in Singaporeans' (ST, 10 May 2003: 1).

Q 2.2 examined the contingent factors that influenced the strategies of the organization in the crisis. Threats appeared to predominantly influence attack $(85.4 \%)$, denial $(33.3 \%)$, justification $(70.0 \%)$, corrective action $(76.0 \%)$, co-operation (47.2\%) and full apology (50.0\%); while the external public and issue under question seem to equally influence denial (33.3\%); industry environment predominately influenced excuse (100\%); and general culture influenced ingratiation (37.5\%) predominantly. The association among the strategies and contingent factors was significant $\left(\chi^{2}=50.365, p<.01\right)$. 
In addition, the organization's choice of strategies was found to be associated with its stance $\left(\chi^{2}=537.499, \mathrm{p}<.001\right)$ : Attack, denial and justification seemed to be predominantly associated with a highly advocatory stance $(86.6 \%, 100 \%$ and $40 \%$, respectively). Corrective action seemed to be predominantly associated with an advocatory stance $(48 \%)$. Excuse seemed to be predominately associated with a lesser advocatory stance (100\%). Ingratiation and co-operation seemed to be predominately associated with a very accommodative stance $(87.5 \%$, $43.1 \%$, respectively). Full apology seemed to be predominantly associated with accommodative and highly accommodative stances $(50 \%$ and $50 \%$, respectively). This suggests that crisis communication strategies were influenced by the organization's strategy moving along the accommodation continuum.

Q 3.1 examined the perception of the government and its multiple publics in the crisis situation, regarding crisis attribution and crisis damage severity. Both the government and its publics perceived the SARS crisis as generally externally controllable at the early stage of the crisis, and both perceived it as generally internally controllable at the later stage of the crisis. In terms of crisis damage severity, the government perceived it to be more severe $(M=6.79)$ than did the publics $(M=6.52)$. The paired samples t-test showed that the difference was significant $(\mathrm{t}=2.526, \mathrm{p}<0.05)$.

Q3.2 examined the multiple publics' perception of the organization's performance and Q 3.3 examined the contingent factors that affected the publics' perception of the organization's performance in the crisis. The publics' aggregate perception of the government performance in dealing with the SARS crisis seemed to be satisfactory $(M=4.85)$. The predominant contingent factor affecting their perception was the factor of threats $(37.2 \%)$. Significant mean difference was found by comparing the perception of the government's performance among the five publics $(\mathrm{F}=5.83, \mathrm{p}<0.001)$. Interestingly, the quarantined public and the general public felt most satisfied with the government's performance while the WHO and neighboring countries were reported as the least satisfied. Also, the publics' perception of the organization's performance was significantly associated with the contingent factors $\left(x^{2}=190.601, p<.001\right)$ and the strategies the organization employed $\left(X^{2}=125.120, p<.001\right)$.

Q4.1 examined the multiple publics' emotion toward the organization in the crisis situation, and Q 4.2 examined the contingent factors that influenced the publics' emotion towards the organization in the crisis. 
The publics' aggregate emotion towards the government performance in the SARS crisis seemed to be positive $(\mathrm{M}=4.79)$ and slightly intensive $(\mathrm{M}=4.19)$. The predominant contingent factor affecting both the emotional tone and emotional temperature was the factor of threats $(22.5 \%)$. Significant mean difference in emotional temperature (intensity) $(\mathrm{F}=5.65$, $\mathrm{p}<.001$ ) was found by comparing the five publics via ANOVA, while there was no significant difference in the five publics' emotional tone (valence). The general public were reported as the most emotionally intensive public while service professionals were the least emotional public. Also, the publics' emotional tone and emotional temperature toward the organization were significantly associated with the contingent factors $\left(\chi^{2}=268.812, p<.001 ; \chi^{2}=318.245, p<.001\right)$, and the emotional tone was significantly associated with the strategies the organization employed $\left(\chi^{2}=82.386, p<.05\right)$. For instance, one public that the government consistently supported and lauded was the service professionals (i.e., healthcare workers) who were caring for the SARS victims. When it emerged that some Singaporeans were ostracizing these service professionals, for fear of being infected by them, it riled the general public into adopting the same stance as the government against such behaviour (ST, 6 April 2003: 4).

\section{Discussion}

\section{Media in Strategic Communication during Crisis Governance} One reason, suggested by a WHO advisor, why Singapore won its fight against the rampant spread of SARS so quickly was the government's ability to win the publics' trust (ST, 1 October 2004: 26). This was exemplified in its ability to effectively communicate with its publics during the crisis (ST, 22 September 2004: H7). Indeed, most, if not all, government crisis communication was disseminated through the media, and it was evident that, in this regard, The Straits Times had performed its role as supporting the government in crisis governance with aplomb. This development journalism approach, where there is a co-operative relationship between the media and the government, is a situation, in most parts, accepted and preferred by the Singapore public. The media act as a 'mediator between the government and the public' and the public 'feels that it is well informed [about] what the government is doing' (Tan et al. 1998: 209). Despite this 'pro-government stance', the public has a high regard for the media in most issues, 
with the exception of coverage of domestic politics and opposition parties (Hao 1996: 121).

The Singapore government, for its part, did not make any apology for what it regarded as the responsibilities of the media. In a recent speech, in response to its low ranking in media freedom $\left(140^{\text {th }}\right.$ out of 167) by the Paris-based agency 'Reporters Without Borders', senior minister Goh Chok Tong reiterated that the media should, amongst other things, advance 'society's collective interest', and work for the 'public good' (ST, 1 November 2005:3). Indeed, the level of co-operation between the government and the media, particularly The Straits Times, in the reportage of a national crisis like SARS was so intertwined that the government had no qualms about rapping the newspaper publicly for publishing the name of the first SARS victim, despite being told not to do so (ST, 7 May 2003).

\section{Proactive Advocacy:}

\section{A Hallmark of the Singapore Government Management Style} Our findings indicate that throughout the life-cycle of the crisis, the government and its publics' stances were constantly moving along a continuum from advocacy to accommodation. To a large extent, most of the publics followed the same stance of accommodation as the Singapore government. However, the government seemed to adopt a more advocatory stance in dealing with two publics - the quarantined public and general public - while these two publics appeared more accommodating to the organization across time. For instance, when the SARS virus began to spread more rampantly in March, the government invoked the Infectious Diseases Act to home quarantine more than 800 people for 10 days to curb the spread of the disease (ST, 25 March 2003: 1). Those quarantined were mainly those who had been in contact with people who had fallen ill. When that measure failed to the situation, the government took the 'unprecedented' step of ordering all schools to be shut down, affecting more than 600,000 students, to prevent schools from becoming breeding grounds. 'The whole idea of closing the schools is to minimize large groups of students having close contact' the health minister stated (ST, 27 March 2003: 1). The school closures were further extended in April. The education minister described the exercise as 'putting in precautions to safeguard our children' (ST, 6 April 2003: 1).

This measure illustrates the decision-making ability of the government to put in place what one newspaper columnist termed as 'bold and fast 
moving' (ST, 17 April 2004: H15) social policies that required adherence. At the same time, the government also managed to win the support of the publics. This is consistent with Sikorski's (1996) assertion that the Singapore government is proactive in taking the lead and advocating judgement calls when it is confronted with threats to the country's survival, particularly political threats, which, in this case, could be extended to biological threats as well. This 'pre-emptive-cum-proactive leadership' (ST, 24 August 2004:13) was evident even after Singapore was declared SARS-free. A day after the WHO's declaration, the government stated it was going back to the drawing board, this time to fine-tune measures for any future similar occurrence (ST, 1 June 2003: 1).

The rationale for advocacy for the quarantined public and general public appeared to be thus: The quarantined public had to be told what to do so that it did not infect the general public, and the general public had to be told what to do so that the virus would not spread any further.

\section{Political Realism: Dealing with Important Publics}

Analysis of news coverage has shown that with publics such as WHO and neighbouring countries like Malaysia, the Singapore government appeared to adopt a more accommodative stance. The political realism in international relations, argued Zhang et al. (2003), is that even though advocacy may be used at first, to maintain harmonious relations, this would eventually give way to accommodation. Two reasons are proffered on why Singapore accommodated and showed deference towards WHO and neighbouring countries. First, Singapore was co-operating closely with the WHO, a world body, to ensure that all measures were in place to prevent the spread of the disease. For instance, when SARS became more widespread globally by the end of March, the WHO called for more stringent airport screening (ST, 28 March 2003: 1). Within three days, airport checks at Singapore's Changi airport had been tightened (ST, 31 March 2003: 1). When the hallmark of a relationship is that of co-operation, accommodation almost always takes precedence over advocacy.

Second, an accommodative stance towards its neighbours, particularly Malaysia, is consistent with Singapore's long-standing relations, based on political realism, national and diplomatic interests (Nathan 2002). Instead of engaging in politics of one-upmanship, for instance, or engaging in quarrels about who infected the virus to whom, the policy of the Singapore government appeared to focus the attention on how the threat (i.e., a common enemy, the SARS virus) could be nullified. On 5 
April 2003, The Straits Times published a statement from the Singapore prime minister's office saying that Singapore and Malaysia had agreed to co-operate closely in the war against SARS by sharing information, research findings and experience (ST, 5 April 2003: 7). This is consistent with Cameron and his colleagues' argument that the prevailing situational variables that facilitate accommodation are the urgency of the situation and the obvious threats in the environment (Yarbrough et al. 1998; Cancel et al. 1999; Cameron et al. 2001).

\section{More Accommodation than Advocacy}

The findings further suggest that crisis management is contingent in nature, associated with the contingent factors. In this study, the authors found more instances of accommodation than advocacy, with advocacy towards selected publics, based on power relationships and the stakes involved. A wide range of crisis communication strategies were utilized by the government in dealing with its multiple publics, which differed according to their power relationship with the organization, occupation and risk levels in the crisis situation. Obviously, the organization used a different set of strategies which might be assumed to best target each public according to their different characteristics. For example, the predominant strategies the government employed in communicating with the WHO were co-operation and corrective action, which is a reasonable communicative response towards a prestigious health organization, in view of its power and influence. On the other hand, the predominant strategies the government employed in communication with the quarantined public were attack, followed by co-operation, which might be explained by the fact that the government had to take demanding measures in controlling the virus but still tried to resolve the problem by collaborating with this key public. Again, threats seemed to be the predominant factor affecting the strategy. This is consistent with previous studies analysing the nature of conflict in the organization-public relationship, where threat was found to be a predominant factor (Shin et al. 2003a, 2003b).

\section{Accommodation in the Midst of Advocacy}

Shin et al. (2003b) suggest that the type of stances an organization adopts towards its publics is also dependent on the type of organization involved. They found that non-profit organizations were more likely to be more accommodative towards its publics, and vice-versa, than forprofit organizations. This was because non-profit organizations were usually 'seen as the "good guys" of society - high-minded, compassionate 
organizations whose members worked to help people achieved a better life' (Wilcox et al. 2002: 410).

In the SARS case, since the organization was a governmental organization, particularly one that is inclined to proactive advocacy, the Singapore government was seen to adopt an advocatory stance when it deemed the threat to be the overriding factor. At the same time, it adopted accommodative stances to 'sugar', if you will, the seemingly harsh medication it was advocating. For instance, while the Singapore government advocated and imposed strict regulations on the quarantine of infected patients and care-givers, especially after it became known that more medical practitioners such as nurses were becoming infected by their patients (ST, 9 April 2003: 1), it also promptly instituted measures to provide financial relief. The health minister announced heavily subsidized hospital rates and drugs for SARS victims; and full absorption of medical bills for practitioners, in what the health minister described as 'bearing the brunt' of the outbreak (ST, 11 April 2003: 1).

\section{How the Publics Perceived the Crisis}

A comparison of the multiple publics' perception of the crisis with that of the organization produced interesting findings. As Gonzalez-Herrero and Pratt (1996) suggest, the publics' perception of the crisis transpires in a dynamic way, depending on the crisis situation. Our results revealed that the government, on the whole, often perceived the SARS crisis to be more severe than did the publics. The day the WHO declared Singapore to be SARS-free, the Singapore government maintained a cautious stance. Its statement noted: 'So long as there are SARS-infected areas in the region and the world, we cannot afford to let our guard down' (ST, 31 May 2003: 1). This could be, as Chong (2001) argued, the hallmark of the Singapore government's handling of issues of survival. By over-emphasizing the severity of a crisis, it erred perhaps on the side of over-managing rather than under-managing.

That probably explains why the government consistently regarded the crisis to be internally rather than externally controllable. The government's approach could be summed up in the prime minister's statement when he formed a high-level task force to tackle SARS: 'So that if something happens, we are ready, we don't panic ... To the best of our ability, we are ready to try and cope with the new problem' (ST, 7 April 2003: 1). Resolution of crisis, it seems, like survival, is never to be left to chance.

A key aspect of this strategy, then, was to manage the publics' perception of the organization's performance as well as their emotion towards 
the organization. As an example of successfully dealing with the SARS crisis while maintaining its reputation and image, the Singapore government seemed to gain understanding and support from its publics in general across time. Our findings show that the publics were largely satisfied with what the government did, and evinced a positive feeling towards it. Chong (2001:37) argued that the Singapore government had indeed built a reputation for 'reliability, integrity, and efficacy ... in the management for survival'.

\section{Implications}

Overall, this study suggests both practical and theoretical implications for crisis management scholars and practitioners. Practitioners, particularly those at governmental levels, can understand the opportunities and challenges of crisis management practice by identifying the contingent factors associated with the stances of its different publics, and by using appropriate strategies to maintain the organization-public communication and by fostering a good working relationship to resolve the crisis. A key strength of the contingency theory is that it allows us to understand the dynamic nature of the crisis and to make judgements on what stances and strategies are appropriate at every juncture.

At the heart of the matter is the fact that it is not so simple to know exactly what works and what does not. It is the authors' hope that this initial effort to analyse how a particular government manages a crisis, not just at the local level, but also with worldwide implications, can provide some exploratory information for other researchers to pursue. Admittedly, one limitation of this study is that it analyses the stance and strategies based on media reports. The inherent limitation in a content analysis of news coverage is superseded by the exigency of the crisis and the imperative for the government to communicate the crisis through a media outlet that it trusted. Rather than positioning our paper as fully reflective of what the government did, we moderate our claims by emphasizing that this is one reading of what happened. This does not invalidate our findings of the factors that influence government stance, and how the publics responded in return.

Further research, through examination of messages disseminated on television broadcasts, government press releases, as well as interviews with officials involved in communicating SARS, may substantiate and triangulate our findings, or they may provide other insights outside the scope of this study. 
Another limitation is that this study is focused on one country, which, in turn, limits the generalizability of how the strategies can be extrapolated to other countries. Future research could explore how other countries deal with the similar types of crisis, and assess the contingent factors that influence the stance or strategies of an organization and its publics. The subsequent findings would provide better conceptual understanding of the operationalizations of those key aspects in crisis management. Additional research could also be conducted to understand the role of the news media as a third party in organization-public relationship development across the crisis life-cycle.

Yan Jin is an Assistant Professor at the School of Mass Communications at Virginia Commonwealth University, Richmond, Virginia, Augustine Pang is a doctoral candidate at the Missouri School of Journalism, University of Missouri-Columbia, USA.

Glen T. Cameron is Professor and holds the Maxine Wilson Gregory Chair in Journalism at the Missouri School of Journalism, University of MissouriColumbia, USA.

\section{REFERENCES}

Barton, L. 1994. 'Crisis Management: Preparing for and Managing Disasters'. Cornell Hotel and Restaurant Administration Quarterly 35(2): 59-66.

Booth, S. A. 1993. Crisis Management Strategy: Competition and Change in Modern Enterprises. London: Routledge.

Burnett, J. J. 1998. 'A Strategic Approach to Managing Crisis'. Public Relations Review 24(4): 475-85.

Cameron, G. T., Fritz Cropp and Bryan H. Reber. 2001. 'Getting Past Platitudes: Factors Limiting Accommodation in Public Relations'. Journal of Communication Management 5(3): 242-61.

Cancel, A. E., Glen T. Cameron, Lynn M. Sallot and Michael A. Mitrook. 1997. 'It Depends: A Contingency Theory of Accommodation in Public Relations'. Journal of Public Relations Research 9(1): 31-63.

Cancel, A. E., Michael A. Mitrook and Glen T. Cameron. 1999. 'Testing the Contingency Theory of Accommodation in Public Relations.' Journal of Public Relations Research 25(2): 171-97.

Chong, A. 2001. '"Singapore Incorporated" and the "Fine City": Gains and Sacrifices in Image Building in Singapore's Foreign Policy of Economic Survival'. Proceedings from the Image, the State, and International Relations Conference. London, England.

Cohn, R. 2002. The PR Crisis Bible. New York: St Martin's Press.

Coombs, W. T. 1998. 'An Analytic Framework for Crisis Situations: Better Responses From a Better Understanding of the Situation'. Journal of Public Relations Research 10 (3): 177-191.

Coombs, W. T. 1999. Ongoing Crisis Communication. Thousand Oaks, CA: Sage. 
Cowden, K. and Timothy L. Sellnow. 2002. 'Issues Advertising as Crisis Communication: Northwest Airlines: Use of Image Restoration Strategies during the 1998 Pilots' Strike'. Journal of Business Communication 39(2): 193-219.

Davis, S. C. and Andrew D. Gilman. 2002. 'Communications Coordination'. Risk Management 49(8): 38-44.

Dougherty, D. 1992. Crisis Communications: What Every Executive Needs to Know. New York: Walker.

Fearn-Banks, K. 2002. Crisis Communications: A Casebook Approach. New Jersey: Lawrence Erlbaum.

Ferguson, S. D. 1999. Communication Planning. Thousand Oaks, CA: Sage.

Fink, S. 1986. Crisis Management: Planning for the Inevitable. New York: AMACOM.

Gonzalez-Herrero, A. and Cornelius B. Pratt. 1996. 'An Integrated Symmetrical Model for Crisis-Communications Management'. Journal of Public Relations Research 8(2): 79-105.

Grunig, J. E. and L. A. Grunig. 1992. 'Models of Public Relations and Communications'. In J. E. Grunig (ed.), Excellence in Public Relations and Communication Management. New Jersey: Lawrence Erlbaum: 285-326.

Grunig, J. E. and T. Hunt. 1984. Managing Public Relations. New York: Holt.

Hao, X. M. 1996. 'The Press and Public Trust: The Case of Singapore'. Asian Journal of Communication 6(1): 111-23.

Harrison, S. (ed.) 1999. Disasters and the Media. London: Macmillan.

Henry, R. A. 2000. You'd Better Have a Hose if You Want to Put out the Fire. California: Gollywobbler.

Jin, Y. and G. T. Cameron 2003. Rediscovering Emotion in Public Relations: An Adapted Appraisal Model and an Emotion-Laden Contingency Plane. Unpublished manuscript.

Krippendorff, K. 2004. Content Analysis: An Introduction to Its Methodology (2 ${ }^{\text {nd }}$ edition). Thousand Oaks, CA: Sage.

Kuo, E. and Peng H. Ang 2000. 'Singapore'. In S. Gunaratne (ed.), Handbook of the Media in Asia. New Delhi: Sage: 402-28.

Leichty, G. 1997. 'The Limits of Collaboration.' Public Relations Review 23(1): 47-58.

Lukaszweski, J. E. 1997. 'Establishing Individual and Corporate Crisis Communication Standards: The Principles and Tools'. Public Relations Quarterly 42(3): 7-15.

Marra, F. J. 1998. 'Crisis Communication Plans: Poor Predictors of Excellent Crisis Public Relations. Public Relations Review 24(4): 461-84.

Martinelli, K. A. and William Briggs. 1998. 'Integrating Public Relations and Legal Responses during a Crisis: The Case of Odwalla, Inc.'. Public Relations Review 24(4): 443-60.

Massey, J. E. 2001. 'Managing Organizational Legitimacy: Communication Strategies for Organizations in Crisis'. Journal of Business Communication 38(2): 153-82.

Nathan, K. S. 2002. 'Malaysia-Singapore Relations: Retrospect and Prospect'. Contemporary Southeast Asia 24(2): 385-411.

New York Times, 27 April 2003; 24 May 2003.

Pauchant, T. C. and Ian I. Mitroff. 1992. Transforming the Crisis-prone Organization. San Francisco: Jossey-Bass.

Plowman, K. D., Cynthia Re Velle, Shira Meirovich, Martha Pien, Richard Stemple, Virginia Sheng and Karen Fay. 1995. 'Walgreens: A Case Study in Health Care Issues and Conflict Resolution'. Journal of Public Relations Research 7(4): 231-58.

Ray, S. J. 1999. Strategic Communication in Crisis Management. Connecticut: Quorum.

Reber, B., Fritz Cropp and Glen T. Cameron. 2003. 'Impossible Odds: Contributions of Legal Counsel and Public Relations Practitioners in a Hostile Takeover of Conrail Inc. by Norfolk Southern Railroad'. Journal of Public Relations Research 15(1): 1-25. 
Riffe, D., Stephen Lacy and Frederick G. Fico. 1998. Analyzing Media Messages. New Jersey: Lawrence Erlbaum.

Rosenthal, U. and Alexander Kouzmin. 1997. 'Crises and Crisis Management: Toward Comprehensive Government Decision-making'. Journal of Public Administration Research and Theory 7(2): 277-305.

Seegar, M. W. and Robert R. Ulmer. 2002. 'A Post-crisis Discourse of Renewal: The Cases of Malden Mills and Cole Hardwoods'. Journal of Applied Communication Research 30(2): 126-38.

Sikorski, D. 1996. 'Effective Government in Singapore: Perspective of a Concerned American'. Asian Survey 36(8): 818-903.

Shin, J., Glen T. Cameron and Fritz Cropp. 2003a. Asking What Matters Most: A National Survey of PR Professional Response to the Contingency Model. Paper presented at the Association for Education in Journalism and Mass Communication (AEJMC) Conference, Miami, Florida, August, 2003.

Shin, J., Yan Jin, I-Huei Cheng and Glen T. Cameron. 2003b. Tracking Messy Organization-Public Conflicts: Exploring the Natural History of Conflict Management through the News Coverage of Unfolding Cases. Paper presented at the International Communication Association Conference, San Diego, California, May 2003.

Shin, J., I-Huei Cheng, Yan Jin and Glen T. Cameron. 2005. 'Going Head to Head: Content Analysis of High Profile Conflicts as Played out in the Press'. Public Relations Review 31: 399-406.

Straits Times (ST). 25 March 2003; 27 March 2003; 28 March 2003; 6 April 2003; 7 April 2003; 9 April 2003: 11 April 2003; 17 April 2004; 4 May 2003; 10 May 2003; 21 May 2003; 27 May 2003; 31 May 2003; 1 June 2003; 7 October 2003; 22 September 2004; 6 October 2004; 1 November 2005.

Tan, L. K, Xiao Ming Hao and Yanru Chen. 1998. 'The Singapore Press as a Mediator between the Government and the Public'. Media Asia 25(4): 204-12.

Turnbull, M. 1995. Dateline Singapore. Singapore: Singapore Press Holdings.

Ulmer, R. R. 2001. 'Effective Crisis Management through Established Stakeholder Relationships'. Management Communication Quarterly 14 (4): 590-615.

Warrington, W. 1997. Intimate Journalism. Thousand Oaks, CA: Sage.

Wigley, S. 2003. 'Relationship Maintenance in a Time of Crisis: The 2001 Oklahoma State University Plane Crash'. Public Relations Quarterly 48(2): 39-42.

Wilcox, D. L., Glen T. Cameron, Philip H. Ault and Warren K. Agee. 2002. Public Relations: Strategies and Tactics ( $7^{\text {th }}$ edn). New York: Allyn \& Bacon.

Yarbrough, C. R., Glen T. Cameron, Lynne M. Sallot and Allison McWilliams. 1998. 'Tough Calls to Make: Contingency Theory and the Centennial Olympic Games'. Journal of Communication Management 3(1): 39-56. 